\title{
The nursing actions before the right to worthy death of the hospitalized child ${ }^{a}$
}

\author{
As ações de enfermagem frente ao direito à morte digna da criança hospitalizada \\ Las acciones de enfermería sobre el derecho a la muerte dignadel niño hospitalizado
}

Nathalia Cristine Schuengue

Pimentel Cholbi ${ }^{1}$ (D)

Isabel Cristina dos Santos Oliveira ${ }^{1}$ (ID

Sandra Alves do Carmo ${ }^{1}$ (i)

Rita de Cassia Melão de Morais ${ }^{2}$ (1)

Elena de Araújo Martinez ${ }^{3}$ (a)

Luciana de Cássia Nunes Nascimento ${ }^{4}$ (10)

1. Universidade Federal do Rio de Janeiro.

Rio de Janeiro, RJ. Brasil.

2. Universidade de Brasília. Brasília, DF. Brasil.

3. Fundação Oswaldo Cruz. Rio de Janeiro,

RJ, Brasil.

4. Universidade Federal de Espírito Santo.

Vitória, ES. Brasil.
Corresponding author:

Nathalia Cristine Schuengue Pimentel Cholbi. E-mail: naty.schuengue@gmail.com.

Submitted on $01 / 23 / 2019$.

Accepted on 04/15/2019.

DOI: 10.1590/2177-9465-EAN-2018-0356

\section{Abstract}

Objectives: To describe the nursing actions facing the right to worthy death of the child and to analyze the (im) possibilities for promoting worthy death of the hospitalized child. Method: Qualitative approach based on the concept of a worthy death, with 16 members of the nursing team, who work in a pediatric hospitalization unit, through the Non-Directive Interview in Group. Data submitted to thematic analysis. Results: The actions minimize the suffering and make the environment more welcoming for the child and family. A dignified death is possible when the child and family are prepared; the decisions are shared; the bond with the team is established; the religious and bioethical aspects are respected and the framework of irreversibility is recognized. These factors guarantee the strengthening of the family; the bioethical principles; the acceptance of the child's death, and the mitigation of the stressors aspects. Conclusions and implications for practice: The nursing team promotes the dignified death of the child based on individual convictions of dignity, since there are no models of care for the child at the final moment of life and death yet, in the unit, the study scenario. Such actions contribute to the creation of new models of care for the child that safeguard primarily the human dignity at the time of death.

Keywords: Hospitalized Child; Death; Nursing Team.

\section{REsUMO}

Objetivos: Descrever as ações de enfermagem frente ao direito à morte digna da criança; analisar as (im)possibilidades para promoção da morte digna da criança hospitalizada. Método: Qualitativo baseado no conceito de morte digna, com 16 membros da equipe de enfermagem atuantes em uma Unidade de Internação Pediátrica, através da Entrevista Não Diretiva em Grupo. Dados submetidos à análise temática. Resultados: As ações minimizam o sofrimento e tornam o ambiente mais acolhedor para criança e família. A morte digna é possível quando a criança e família são preparadas; as decisões são compartilhadas o vínculo com a equipe é estabelecido; os aspectos religiosos e bioéticos são respeitados e o quadro de irreversibilidade é reconhecido. Esses fatores garantem o fortalecimento da família; os princípios bioéticos; a aceitação da morte da criança, e a atenuação dos aspectos estressores. Conclusões e implicações para a prática: A equipe de enfermagem promove a morte digna da criança baseada em convicções individuais de dignidade, uma vez que ainda não existem modelos de cuidado à criança no momento final de vida e morte, na unidade, cenário do estudo. Tais ações contribuem para criação de novos modelos de cuidado à criança que resguardem, prioritariamente, a dignidade humana no momento da morte.

Palavras-chave: Criança Hospitalizada; Morte; Equipe de Enfermagem.

\section{Resumen}

Objetivos: Describir las acciones de enfermería frente al derecho a la muerte digna del niño; para analizar las (im) posibilidades para la promoción de la muerte digna del niño hospitalizado. Método: Cualitativo basado en el concepto de muerte digna, con 16 miembros del equipo de enfermería actuantes en una Unidad de Hospitalización Pediátrica, a través de la Entrevista No Directiva en Grupo. Datos sometidos al análisis temático. Resultados: Las acciones minimizan el sufrimiento y hacen el ambiente más acogedor para el niño y familia. La muerte digna es posible cuando el niño y la familia están preparados; las decisiones son compartidas; el vínculo con el equipo es establecido; los aspectos religiosos e bioéticos son respetados y el cuadro de irreversibilidad es reconocido. Estos factores garantizan el fortalecimiento de la familia; los principios bioéticos; la aceptación de la muerte del niño, y la mitigación de los aspectos estresores. Conclusiones e implicaciones para la práctica: El equipo de enfermería promueve la muerte digna del niño basada en convicciones individuales de dignidad, ya que aún no hay modelos de cuidado para el niño en el momento final de la vida y la muerte, en la unidad, el escenario del estudio. Estas acciones contribuyen a la creación de nuevos modelos de cuidado al niño que resguarden de manera prioritaria, la dignidad humana en el momento de la muerte.

Palabras clave: Niño Hospitalizado; Muerte; Equipo de Enfermería 


\section{INTRODUCTION}

The advent of technologies brought great advances and improvements in healthcare, however enable maintaining the life at any cost, impairing the human dignity. ${ }^{1-2}$ It is necessary to understand that the dignity, even at the time of death, is fundamentally an attribute of the human being, making it worthy of respect and protection, no matter his or her origin, race, gender, age, marital status or socioeconomic condition from the moment of conception. ${ }^{3}$

The concept of human dignity is, primarily, the need of protection of the primary interests of any person by means of basic conditions for its existence, as well as protection of its personal autonomy. ${ }^{4}$

The scientific advances, in general, and the advances in medicine have enabled the prolongation of the children's life with life-threatening diseases, until then irrecoverable. The fact that there is ever more control of the biological aspects of the health/disease process, possibly, promotes limitations in the health professionals' sensitivity to admit the treatment failure and implement supporting and palliation measures more compatible with the care that respect the human life. ${ }^{5}$

Before the complexity of the aspects that involve the promotion of the human dignity at the moment of death and, that there should be consistent proposals of care of end-of-life for the child and its family, is indispensable a common language between researchers and health professionals about the concept of worthy death ${ }^{6}$, as well as the concept of Palliative Care.

Palliative Care "are an approach for the improvement of the quality of life of patients and relatives who face a threatening disease of life, through the prevention and the suffering relief, through the previous identification and impeccable evaluation and treatment of the pain and other physical, psychosocial and spiritual problems". 7

Based on the concepts ${ }^{6,8-9}$, this study considered to be a worthy death the one that occurs after the relief of the symptoms which leads to suffering and establishment of the maximum comfort, having been respected the desires and wishes of the child and its family, as well as its cultural and spiritual aspects, occurring in an welcoming environment, in that the child is not alone.

The worthy death as a right must be studied and discussed, since the same represents a paradox in the Federal Constitution, which emphasizes as only the right to life, ceasing to preserve the principle of human dignity in situations of death. ${ }^{2}$

It is important to emphasize that the $20^{\text {th }}$ item of the Resolution No. 41/1995 of the Brazil's National Council of the Rights of the Child and the Adolescent (CONANDA) guarantee to all hospitalized children and adolescents the right of having a worthy death, together with their relatives when exhausted all the available therapeutic resources. ${ }^{10}$

The literature points out that negative aspects such as the association of care strictly related to the cure for the disease, the position of indifference of some professionals, the suffering, the bereavement badly lived, the lack of theoretical and practical knowledge are factors that make it difficult to guarantee the right of the child of dying worthily. Despite this evidence, the reduced number of studies indicates an existing gap in the knowledge about the nursing actions to meet the right of worthy death of hospitalized children. ${ }^{1,11-13}$

Therefore, the study has as object the nursing actions before the right of the hospitalized child to a worthy death. The objectives are to describe the nursing actions before the right of the hospitalized child to a worthy death and, analyze the (im)possibilities of the promotion of the worthy death of the hospitalized child.

\section{METHODS}

Study of qualitative nature, based on the concepts of worthy death $^{6,8-9}$ developed in a pediatric hospitalization unit of an university pediatric hospital situated at the Municipality of Rio de Janeiro.

The referred unit has forty-six beds, of which thirty-two are destined for children with acute diseases, as well as children with chronic diseases dependent on technologies, eight beds destined for children with surgical pathologies and six beds for children with hematological diseases.

The nursing team of the Pediatric Hospitalization Unit is composed of twenty nurses and seventy two nursing technicians. Of this quantity of professionals, seven nurses and nine nursing technicians selected from the inclusion and exclusion criteria participated in the study.

The inclusion criterion was the time of experience in caring of the hospitalized child in the Pediatric Hospitalization Unit of at least one year, due to understand that, from this period, the participant was more likely to experience the process of dying and the death of the hospitalized child in this scenario. The exclusion criterion was the holiday coverage, licenses and deployment of professionals from other sectors to the pediatric hospitalization unit, since the nursing actions in other scenarios are different from the actions developed in the unit, the scenario of the study, and might interfere with the external validity of the results. ${ }^{14}$

The data were collected in the months of January to April 2018, with the use of the form for the participants' characterization and by means of the non-directive interview in group. The local of choice for the data collection was a room reserved in advance, in the pediatric hospitalization unit, scenario of the study. In this room, we established a banner with the themes on a wall, one round table and chairs organized in a semi-circle to obtain a better view of the banner for conducting the non-directive interview in Group.

By bringing together the group, each professional received two copies of the Free and Informed Consent Form (FICF), according to the requirements of the Resolution No. 466 of 12 December 2012 of the National Health Council (CNS), which 
provides guidelines and regulatory norms for research involving human beings. The FICF was read aloud by the researchers and, all items contained in the term were elucidated. After signing the FICF, each participant developed a copy for the researcher, remaining with the other copy.

After signing the Consent Terms, the researcher fulfilled the form of the participants' characterization that addresses three aspects: identification data, data related to the formation and professional activity. Subsequently, it began the Non-directive Interview in Group.

Five interviews were carried out, with groups of 3 to 4 participants, having at least one nurse in each group that had, on average, duration of thirty five minutes and eight seconds. In this technique of interview there is no formulation of questions to the interviewee, being presented themes, to the group of participants, with the aim at encouraging reflections, allowing the participants to develop and deepen their ideas in a spontaneous manner, avoiding authoritarian or paternalist attitudes, by the researcher ${ }^{15}$.

The guiding themes of the interview are elaborated based on the conceptual framework and in the bibliographical review about the theme. The themes were placed in a panel during the interviews and validated in the first interview, being them: attendance of the biopsychosocial needs of the child and its family; welcoming environment; interventions for prolonging the life; the right to worthy death /legislation; relief of the disabling symptoms; respect to the beliefs and religion; relationship of trust with the child, family and team; decision taking and interventions/ family. It is worth mentioning that the concept of worthy death was not presented to the participants, before the interview.

The carrying out of each interview was followed by the transcription and the thematic analysis ${ }^{16}$, which allowed to delimit, gradually, the intensity of the sociocultural dimension of the existing of the studied phenomenon. From the results obtained with the fifth interview, it considered, a priori the internal logic of the study object, as well as the connections and interconnections existing between the child, family and nursing team, that permeate the final moment of the child's life in the pediatric hospitalization unit, opting for ceasing the carrying out of the interviews, facing the internal saturation criterion of the data ${ }^{17}$.

The study respected the formal requirements of researches with human beings, according to the Resolution No. 466 of 12 December 2012 of the National Health Council (CNS), approved by the Ethics Research Committee of the Institution, scenario of the study, by means of the opinion No. 2.420.88 (CAAEE 76061517.8.3001.5264), approved on 7 December 2017. The participants were identified with alphanumeric codes of $E=$ Nurse (E1 to E7) and T = Nursing Technician (T1 to T9) .

\section{RESULTS}

In relation to the participants, nine worked as nursing technicians and seven as nurses. With regard to the identification data, were 15 participants of the female gender, aged between
27 and 54. In relation to the professional relation 14 participants had graduate nursing; four had specialization sensu latu sensu in Pediatrics and six in other areas such as Intensive Therapy, Neonatology, Cardiology, and Family Health; five had master in areas as Child Health and Management. The time of service in the institution ranged from 1 to 20 years.

Based on the testimonies, three thematic units emerged: Nursing actions before, during and after the child's death; (Un) known of the nursing team about the worthy death of the hospitalized child; and, The family and the environment of the hospitalization unit; (im) possibilities for the promotion of the right to worthy death of the hospitalized child.

\section{Nursing actions before, during and after the child's death}

This topic analyze the nursing actions that seek to promote a worthy death for the child in the pediatric hospitalization unit, focusing on the minimization of the child's suffering; the professionals' performance as protectors agents of the child; the expansion visitants/companions of the child; and the nursing team's strategies for the configuring of a more welcoming environment.

In order to minimize the child and the family's suffering, the deponents described actions to alleviate the symptoms, specially, the pain control; oxygen therapy installation when there is respiratory distress; less handling, carrying out body hygiene in a simple way, when possible; and promotion of physical comfort.

Many times medications are done in order to allow to control this part of the pain, sometimes, a respiratory effort. It comes with an oxygen to give any comfort (TE4). I think that, sometimes we have to intervene less to alleviate the symptoms. At this moment, sometimes, this bath in bed highly elaborated will cause more harm than good (E2). We try to negotiate, talk with the medical team the question of a more regular analgesia in some cases [...] (E4) The symptoms relieve I consider fundamental. It's not because the child is dying that you will not carry out the care. You do not need to have pain, you do not need to have anything. (TE6)

With regard to the child's analgesia, the professionals reported the use of morphine dripping, however, they emphasized the possible adverse effects:

Indeed, the dripping of morphine is not authorized. You are avoiding the pain, but it can cause a cardiac arrest. But, sometimes, it end up using... We have the doctor (female) of the pain. When the child is at this moment, we call her. She comes and put all things in order to not have pain. But, that gaspiation, that discomport remain (TE7). Sometimes, we find difficulty to do an effective analgesia with fear of 
that child entering a respiratory depression [...] If I go to look to this way, the child is not having a worthy death (E4). At the time the child is at the moment of death, it receives a dripping of morphine to alleviate the symptom of pain, to try alleviate a bit the suffering of death. (E6)

It was possible to identify that the deponents performed as protectors agents of the child in different moments, not only with regard to the right to not feel pain, as well as ensuring the right to health, in playing, to the education and information, even to ensure them that they have to mediate conflicts with the other members of the health team.

We protect, yes, we protect a lot the family and the child[...] We, at least I, I always fight. I fight with everybody, I fight with the doctor (female), the pharmacy, thus in a general way. I fight to defend anything of the child such as the medicine. Sometimes, the doctor takes a long time to come look [...] then I fight for this. But, is only to protect the child, the mother (TE2). Then, I, having the knowledge, I will surround the family both of information and direct care to this child... To try to protect the right that it has... Basically, our reality is the child has the right to health care, has the right to play. We have the hospital class, they have the right to education (E1). I will administer the medicine $x$, then in general they ask for what is, I always inform if is an antibiotics, an analgesic. I always inform. (TE3)

A participant detached the post-death care as having the last moment of the nursing care to the child and, consequently, the last opportunity of actuating as protector agent.

I like to prepare the body when has the death because I think that is the last stage of care that we can provide to that child, then, I face as a way of protecting that last moment. (E5)

With regard to the presence of the relative/companion, it was possible to verify that seven participants not only ensure the companion the right to stay full time, as well enlarge the presence of relatives and visitants of the child at the last moments of its death alone.

Not only the father and the mother, but also the family. We even encourage the family to bring the brother. This coverage of the family is fundamental and is what will provide really a death with less trauma (E1). That other important persons for the child can come... I believe that yes, for the last moments of the child's life, have a positive contact with somebody who does you good, can be good (TE4). We even break a few the bureaucratic part, we allow the brother come in the moment that he wish, independent of the time in that he comes, because we know that he will die (E6). The own visit extended for me is a biopsychosocial care. If you allow the following of the mother and the father 24 hours per day, is you allow the visit $[. .$.$] (TE3)$

In relation to the environment of the hospitalization unit, the participants emphasized that there is no structurally welcoming environment so that the worthy death of the child can occur, since there is no privacy for the child and its family to experience this moment. However, the deponents reported strategies for configuring an possibly welcoming environment for the child and family. Among the strategies, it emphasized the use of screens and sheets around the bed and interdiction of beds close to, when possible, with the aim of guaranteeing the privacy of the child and its family.

Here we do not have a specific, sometimes, we separate with screens, leaves the mother close and everything. (E3). This insulation that we did was with a same screen, just so people are not looking to expose the child so much. (TE8). Here we even put the screen, sometimes, sheet. But, in a way or another, the children end perceiving because it is not common to have screens, have sheet hanging. (E7) A comfort for the patient. Suddenly, interdict a bed that is in front, so the family is more comfortable (TE2).

\section{(Un) known of the nursing team about the worthy death of the hospitalized child}

This topic describes the (un) known of the nursing team to deal with the worthy death of the child and the communication of the team with the family.

The unknown of the deponents to deal with the worthy death of the child runs through the difficulty of understanding the child in other dimensions, beyond the biomedical sphere. In this way, the professionals mentioned the unpreparedness to deal with the child's death, which influenced directly in the care given to it and in the carrying out of interventions to prolong the life.

To what extent are really prepared to understand. Is it because of the vision of the biomedical model? Treat the disease only? Or see the child as a whole, being the family also included in this care [...] I think that we are not being able to meet the biopsychosocial needs because of the unpreparedness to deal (E4). Interventions to prolong the life I see here as frequent, because we see children without the slightest perspective, life quality and still have an investment (TE9). There, at the moment, the team is not prepared for this. You are not prepared to decide whether you will have to prolong a life or not reanimate 
that child. We get ready to save lives, independent of any other thing. With the passage of time and experience, we are beginning to understand. But, we are beginning to understand. But, at the beginning, we did not understand, it was one of my biggest conflicts. (E5)

On the other hand, the professionals recognized the need of being able to experience this moment next to the child, since they stated the importance of constructing protocols, and realize discussions, reflections and researches about this moment.

If we do not discuss this matter, it will never be more quiet take this type of decision. So, I think important to talk about this. (E2) Team for the final moments. A physician who is responsible only for the pain, do you understand? A nursing team that was oriented for it that had a protocol. Here we have so many researches, it could do a research like this, of doing a group like this. Because here we have researches about everything. We have researches about so many diseases, it might have a research only about this moment. These is here where the dreams begin. With the researches. (TE7)

To speak about the child' death with the family, also configures as a great challenge for the nursing professionals, as evidenced in the testimonies. The professionals reported that they do not know the manner how they should address the matter with the family that, sometimes, this care was realized only by the Palliative Care Commission.

How to talk with a family of a terminal child? What I will say? I can not think exactly the better words, I think that we are exposed to this, we should just know a better way to speak about it, to not be something that at the time you do not know what to say (TE4) This type of thing ends up even getting to the commission. It's because are they the one who address, they who speak about. I don't know if I would have authority to talk about this type of thing with the family, I would like that, at least somebody gives me a support. (E7) Sometimes, the child dies, and the mother comes to talk with us and, sometimes we do not have any words in front of a situation like this [...]l, sometimes, as a health professional, I do not know how to deal with it. I do not know what to say, how to say, how to address at the time. It's very difficult. (TE3) I will be sincere, in order to talk with the child and the family about this, it is very difficult. Having a commission I stay more peaceful, because I know that it is being cared in this sense [...] We know what is happening, the family know what is happening, but I have no much about what to say, what I will tell? To speak clearly about the death I have never spoken. (E6)
On the other hand, some professionals emphasized the communication among the nursing team and the family, mainly with regard to the information regarding the child's general condition and the care provided.

To arrive and speak [...] about what are happening? Until when you want that I stop, to what extent you want me to go? Do you want me to use medicine in your daughter or to use the respirator? (E3) Of everything that exist, of all knowledge and health technology, we've done everything that we could for your son. The next time he (she) stop we wanted to know what you think (E2). When we talk adequately with the family, explaining really the process of the disease and this process of dying, where the child does not have more the possibility of living. It is important that the team can talk and pass this notion for the family. To pass really what was happening, be right. It's best for us to establish this contact. (E1)

\section{The family and the environment of the hospitalization unit: im (possibilities) for promoting the right to worthy death of the hospitalized child}

This topic focuses on the family in front of the child's death in relation to the (un) preparedness to deal with this moment; the shared decision; the establishment of bond and confidence with the team; the religiosity and the spiritual support, as well as the aspects inherent to the environment of the pediatric hospitalization environment.

In front of the terminality condition of the child, the deponents emphasized the importance of the multidisciplinary actions and of the palliative care for preparing the child and its family before the death. The preparation provides the strengthening of the family to the moment of farewell.

A whole family and child for a quality of life, in fact. The family achieve dismissing better. She feels more strengthened to participate in that child's starting time. You see the difference that is this process of dying of a child that has this preparing and its family than the one that does not have. (E1) I think that the family had to be a psychological support to understand, it only is aware of what is alive. (TE6) We try to be the most transparent possible, , but the question of the medical diagnosis is not of our competence and is stays failure due to it does not understand what is really a palliative care and what is a preparation for the death. (E4).

The deponents emphasized situations in which the child and the family expressed wishes and desires, mainly related to the non- realization of interventions to prolong the life and transference to the Pediatric Intensive Therapy Unit, evidencing 
the shared making decision and, consequently, the possibility of promoting the worthy death of the child.

The mother, sometimes, makes the decision not to want of not want to do anything else in it, do not put it on, put it off, turn it off. And there are some patients that even ask, do not want to go to the ITC. That want to stay here. (TE2) The child asked to the doctor, are you my friend? If you are my friend, then let me die. Then, this decision has to be sure the family be participating of this. It's a decision which must be linked to the parents' understanding and, sometimes, till the child. (E2)

On the other hand, the families are not prepared to experience this moment, they do not understand the end-oflife of their sons and express the desire of the medical team of establishing measures that prolong the life, becoming impossible to promoting a worthy death to the hospitalized child. Beyond this, the families express feelings of guilt, suffering and abandonment.

The mother deludes herself a lot because the team does not explain. And says, I did not know it, that my son will die. Because when this child arrives at the moment and it happens, the mother arranges the culprit. (TE2) The parents do not understand that that child needs for comfort to die yet. $B$, they do not understand why is the son. They will want to invest. But, because the actual situation and prognosis of the child. (E4)

Other important aspect that makes it possible the promotion of the worthy death is the trust and the bond established between the child, family and team, since, according to testimonies, when there is bond and trust, the family understand better about the care to be carried out, the suffering of the child and the family reduce, the process of dying becomes less traumatic, make it easy to prepare the family for the death and the mourning, in addition to help family accept the child's death, that is, aspects that make it possible the child to experience a worthy death.

Only through the establishment of trust with the team, I think that we can establish trust with the team, I think that we can implement nursing actions about the right to worthy death. What I usually is that, despite their understanding, whenever death comes, in the act they feel a little insecure, then the relation of trust is essential. (E5) It is fundamental for a worthy death, the establishment of this bond so that the team could talk [...] It is because when we pass on this notion properly, the family acquires a trust in us. When you has a good relationship with the family, when everything is well explained, this process of dying becomes lighter [...] The establishment of the relationship is essential for preparing the family and the child too. (E1) It is a very important thing, I think it makes a great difference at the moment of death. From the moment that the family or the own patient feel that can speak, count on, trust, this improve a lot the response of the patient [....] When the child can perceive in the team someone in that it trusts, facilitates because it suffers less. (TE40) I think that it facilitates until the family accept that the child died. Because if you trust in the team, you believe that everything that could have been done for her son, it was done. (E2)

On the other hand, the deponents mentioned that, in many situations, despite the relationship of trust and of bond established, the parents feel insecure and desperate, what compromises its integrity to remain together with the child, as well as the possibility of the child to experience a peaceful and worthy death.

I think that even that we establish this relationship of trust, doing everything to have this trust with the family and the child, I think that at the moment of death they abstract this, they begin to distrust [...] Did they do everything that was supposed to be done? (TE6) I think it is very complicated, I think that the mother and the father, they do not trust, they stay completely insecure and afraid of what will happen. (TE7)

The religiosity and the spiritual support to child and its family were also emphasized in the testimonies as important aspects that help the family in the assimilation of the child's death. In front of this, the deponents report that they respect the religious leaders and the manifestations of the relatives' faith, and assume a position of neutrality before the families' religiosity.

This is important for the own assimilation of the death. Each one with its religion, with what believes, many times, help to understand the death. It always had much respect independent of the religion. (E1) We always respect, be spirit, be catholic, be evangelical. We always respect the family decision. We respect the taste of each one. That the person has its preference. There is someone that does not prefer anything. I think that in all places, when it treats of death. (TE2) It goes more or less in that situation of opening to what is good for the patient, the visit of any religious leader, any pastor. Something to bring a comfort for the patient if he has a more intense religious practice, more active, both for the child and for the family. (TE4) If permits that the mother keep a small ribbon ranging from her arm ... In addition to the care that we give to the physical health, there are these psychosocial questions too. (TE3) The professional should be neutral, this cannot expose its religion for the family. WE has to support any religion that the family has. (TE7) 
The hospitalization unit environment was mentioned in the testimonies in front of the nuances of impossibilities to promote a worthy death of the child. The deponents considered the pediatric unit environment as inadequate, since it does not provide privacy and comfort to the child and the family, it does not have a space reserved for relatives receiving bad news, and, neither allows that the child and its family enjoy a moment of farewell in a peaceful manner, without the presence of other relatives.

The child die into the nursery, and here she does not have a privacy. (E9) There is not a place that we can gather this family to call the social worker, we even to give a word of support at this moment. (TE3). The mothers do not have privacy. There is not that moment of the farewell. After the child's death, that opportunity of the mother to say goodbye, of the mother to talk. (E7).

However, the deponents emphasized the comfort, the privacy and the humanization, such as suggestions for particularities of a welcoming environment, which would make it possible the child to experience its death worthily. In addition this particularities of the welcoming environment, the deponents emphasized the importance of the existence of a bed separated from the other children to accommodate the child during the final moments of its life.

Welcoming environment is the one where we provides a comfort, both for the patient and for the relative. The welcoming environment is an environment that has privacy (E1) Maybe, separate and give a greater liberty can stay the parents here, visit any person who is important for that child or for the patient, that may enter. That is more humanized. Maybe, a separate bed for this moment, would be a good possibility of becoming this moment more welcoming. (TE4) It would be a more reserved environment, it would be what we could offer with more privacy. (TE9) We could even have a room for this child at this moment, doesn't it? It's very complicated. It could have an antechamber. At least, since it will not do anything, to at least stay with the family. (E5)

The contradictions about the death of the child in the hospitalization unit are also based on medical diagnoses. The deponents mentioned that the great majority of children that die in the hospitalization unit, scenario of the study, has hematological diseases. However, children in process of dying with other medical diagnoses are transferred to the Intensive Therapy Unit.

And our children who are dying here, are not are not bringing to the ICU because they will die, are staying here. There were about three deaths last year in the hematology because it could not take it to the ICU. (TE7). In the hemato is that still stays her, it's not everyone, but the majority die in the nursery. You see that the highest number of experiences with death we have here in the hematology. It's because in the other nurseries, when it gets worse, they really go to the ICU. (TE9)

\section{DISCUSSION}

The nursing team believes that to provide a worthy death, it must prioritize the well-being of the child, implementing pharmacological and non-pharmacological measures that alleviate symptoms, promote comfort and, minimize the suffering. It is necessary that the health team provide care that are focused on the quality of life of the child, and does not foresee the cure for the disease, which allows that the family and the child understand better the situation the situation to be experienced. The quality of life is an attribute to the worthy death concept ${ }^{5}$ that prevails on the futile life and suffering extension.

Moreover, it is important emphasize that when realizing nursing actions that reduce the suffering and alleviate the pain, the deponents assumed the role of the protecting agent of the child, since they ensure the right of the child of "not feel pain, when exist means to avoid it". ${ }^{10}$ The multidimensional actions developed by the nursing team with a view to ensure the rights of the hospitalized child search for, especially, ensuring the right to life and dignity. Considering that the child has vulnerabilities and that they are not fully aware of their rights, it becomes indispensable that the nursing professionals carry out actions of advocacy, ensuring that the child, still is hospitalized, is subject of law. ${ }^{18}$

The wish to carry out care to the child's body reveals the nurse's capacity of recognizing the death as a natural step of the life. This recognition allows that the death is seen under a positive view, as a moment of relief, of rest and, above all, a moment of cessation of the child's suffering. ${ }^{19}$

At seeing the death with tranquility, it is possible to ensure worthy in all moments of the child's life, including after its death. In this perspective, it occurs the preservation of the bioethics principle, indispensable for guaranteeing the child's worthy death. ${ }^{6}$

To experience a less traumatic death, it is necessary that the child is close to its family, as well as its personal objects. In this aspect, at recognizing the final moment of the child's life, the nursing team infringes norms and routines of the institution and increases the number of visits and companions of the child. In addition, the nursing team encourages the presence of the parents and other members of the family, allowing that the child is not alone.

According to the concept of worthy death ${ }^{6}$, the child's death must occur in a welcoming environment, where the comfort and privacy are ensured. In this way, although the nursing team identifies aspects in the environment of the hospitalization unit that become it structurally inadequate, the development of 
strategies related to environment reinforces the concern of the team in guaranteeing the dignity at the moment of the child's death.

Despite carrying out actions that seek to promote the worthy death in the Pediatric Hospitalization Units, the deponents reported recognizing the way how they must deal with the death before the difficulty in understanding the child in other dimensions, beyond the biomedical sphere. In this way, the unpreparedness to deal with the child's death influences directly the care provided for it and in the carrying out interventions to prolong the life.

To deal with death implies to know overcoming the feelings of sadness, unsafety and guilt, in addition to managing personal conflicts about the quality of care. The unknown Deal with the death implies to know and, consequently, the professional unpreparedness to deal with the possibility of the child' $s$ death carry unsafety to stop treatment and the intervention measures, that only prolong the dying process and the child and its family's suffering injuring the bioethical and human principles that permeate the care. ${ }^{11}$

However, the deponents recognized the need to be able to care of the child in its end-of-life. It's essential that the professionals recognize their importance, to be able to make the difference in the life of the other, mainly at the moment of its death. As they understand the process of dying, they start accepting and conducting the death as natural as possible. ${ }^{20}$

The open communication also configures as a great challenge, since it should contemplate the transmission of true information to all persons involved, a care that the care is also extended to the child who experience its process of terminality. Metaphorically, "what kills is the disease, and not the true about her (...) The word that kill is the word used wrongly". ${ }^{20}$

On the other hand, in establishing an effective communication, the nursing professionals allow the family to be protagonist of the care and participate actively in the last moments of the child's life. In this circumstance, the professionals help the parents accept the finiteness of their children's life. ${ }^{21}$ The openness of the communication channel with the family is an important intervention of the nurse, since the worthy death of the child only occurs when there is complicity and veracity among all the persons involved in the care. ${ }^{20}$

To communicate adequately with the child and its family requires skills of the health professionals to transmit honest, true and coherent information. Beyond on establishing an effective communication to meet the process of shared decisions, it is necessary to include the child and the family in the meetings of the team. ${ }^{6}$

It is possible to promote the worthy death when the child, according to its ability of understanding, as well as its relatives are aware of the complete situation of health, from the open communication, and make decisions together with the multidisciplinary team. ${ }^{20}$ To respect the wishes and desires of the child and its family means ensuring its autonomy and, consequently, preserve the bioethical principles that precede the concept of worthy death of the child. ${ }^{6}$

To consider the wishes and desires strengthen the relation of trust and the bond with the child and the family, as well as helps the family maintain the emotional balance and safety, and the capacity of caring the child at the end-moment of its life. However, the family presents ambiguous feelings at the end-moment of the child's life, and, mainly, after death, when they have a relationship with the team, which bond is fragile or was interrupted. ${ }^{13}$

The minimization of the child and its family's suffering also permeates the comfort provided by the cultural aspects, which include values, beliefs and religious traditions. In allowing the presence of religious leaders, as well as manifestations of Faith, the nursing team ensures that the child and its family be respected in other dimensions, to beyond the biological dimension. The religion and the spirituality are mechanisms that help in the better acceptance of the child's health condition, of its process of dying and of its death, besides mitigating stressor aspects. ${ }^{21}$

The environment of the hospitalization unit was considered as inadequate and, that manner, translate impossibilities in the face of promoting the worthy death of the child. In this way, the environment should be considered in face of the possibilities of the death events, not only by the health professionals, but mainly by the organs responsible for the public policies implementation. It is indispensable that measures are established that transform the physical structure of the environment of the hospitalization unit in a welcoming environment and that, above all, safeguard the right to worthy death of the hospitalized child.

The pediatric hospital environment should consider and respect the cultural values, the autonomy, the privacy, the individuality and the ways of life of whom is cared, prioritizing the physical and psychical well-being and its family, beyond of being welcoming, harmonic and humanized. ${ }^{22}$ In this way, the deponents emphasized the comfort, the privacy and the humanization, as particularities of a welcoming environment that make it possible the child to experience its death worthily.

In addition, it is only possible to promote the worthy death of the child when it is recognized the condition of irreversibility of the clinical condition of any condition that threats its life, in front of the prognosis and the therapeutic limitations. ${ }^{6}$

\section{CONCLUSION}

The results of the research allowed us to evidence that the promotion of the child's dignity in the last moments of the life and death has highly complex aspects before the representativeness and the meanings of the death in the society. The inconsistency of the child's worthy death concept in the pediatric hospitalization unit hamper the consolidation of an assistance model that promotes quality of life and ensure the right to a worthy death to all hospitalized children. 
The study described the nursing actions before the right to the worthy death of the hospitalized child, from three concepts of worthy death constructed in the Intensive Therapy Unit, and, adapted to the reality of the Pediatric Hospitalization Unit, which enabled to analyze the (im)possibilities of promoting the right to a worthy death of the hospitalized child, and to discuss the respective implications of the nursing actions for promoting this right.

It has become clear that, the nursing assistance to the child before, during and after its death is based on dependent and independent actions. Relieve pain and other symptoms, from pharmacological measures, as well as to install oxygen therapy are actions that depend on a medical prescription.

On the other hand, it was noted that reduce the handling of the child, encourage the presence of relatives and personal objects, as well as to promote the privacy and comfort to the environment of the hospitalization unit are nursing actions that are independent of other health professionals.

Despite still not existing a model of care to child in conditions of end of life in the hospitalization unit, the dependent and independent actions reveal that the deponents search for promoting the human dignity before, during and after the child's death, according to their convictions of dignity.

The nursing team believes that the worthy death is possible when occurs the preparation of the child and the family to experience this moment; the decisions are made in a shared manner; the relationship with the team is of trust and bond; the religious aspects are respected; the death occurs in a comfortable, private and human environment, and, the clinical irreversible condition is recognized by the health team.

That way, the family remains more strengthened for the farewell moment; the ethical principles are preserved, ensuring the child and family's autonomy; the process of dying and the mourning become less traumatic, with a better acceptance of the child's death; the stressor aspects are attenuated; the welcoming environment; and, the child experience the final moments of the life and death next to the family.

However, it notes the difficulty of ensuring this right due to the nursing team in dealing with death, in communicating bad news, controlling symptoms and the lack of hospital environment that maintains the privacy at the end of the life and death.

The study limitations are related to the specificities of the research scenarios, and the qualitative nature of the study, from a dialectic view, which interprets the subjective aspects that involve the participants inserted in a socioeconomic and cultural context based on the recurrence of the findings obtained without preoccupation with statistical generalizations.

In this sense, the thematic of the nursing assistance before, during and after the child's death, as well as the guarantee of right to a worthy death of the hospitalized child in the pediatric hospitalization unit need to be addressed in the scope of the teaching and research, with the development of new studies, which enable to understand other realities and construct models of care based on the worthy death concept and that ensure all the right of the hospitalized child, including the right to have a worthy death, together with their relatives, when exhausted the available therapeutic resources.

\section{REFERENCES}

1. Kovács MJ. A caminho da morte com dignidade no século XXI. Rev Bioét [Internet]. 2014 Jan/Apr;22(1):94-104. Available from: http://dx.doi. org/10.1590/S1983-80422014000100011

2. Dinel LR, Gomes D. O Direito à Morte Digna. Rev Fac Dir Sul de Minas (Pouso Alegre) [Internet]. 2016 Jan/Jun; [cited 2016 Jan 20]; 32(1):245 72. Available from: https://www.fdsm.edu.br/adm/artigos/3b1f65717a3 ea1ed341007acc6b78de7.pdf

3. Motta AFMR. A dignidade da pessoa humana e sua definição. Âmbito Jurídico [Internet]. 2013 Dec; [cited 2017 Dec 14]; 16(119). Available from: http://www.ambito-juridico.com.br/site/?n_link=revista_artigos_ leitura\&artigo_id=14054

4. Fria L, Lopes N. Considerações sobre o conceito de dignidade humana Rev Direito Gv [Internet]. 2015 Jul/Dec; [cited 2019 Mar 8]; 11(2):649-70. Available from: http://dx.doi.org/10.1590/1808-2432201528

5. Baliza MF, Bousso RS, Poles K, Santos MR, Silva L, Paganini MC Fatores que influenciam os enfermeiros de Unidades de Terapia Intensiva nas decisões de final de vida. Rev Esc Enferm USP [Internet] $2015 \mathrm{Jul} /$ Aug;49(4):572-9. Available from: http://dx.doi.org/10.1590/ S0080-623420150000400006

6. Poles K, Bousso RS. Morte digna da criança: análise de conceito. Rev Esc Enferm USP [Internet]. 2009 Mar;43(1):215-22. Available from: http://dx.doi.org/10.1590/S0080-62342009000100028

7. World Health Organization (WHO). National cancer control programmes: policies and managerial guidelines. Geneva:WHO; 2012.

8. Hendrickson K, McCorkle R. A dimensional analysis of the concept: good death of a child with cancer. J Pediatr Oncol Nurs [Internet]. 2008 May/Jun;25(3)127-38. Available from: https://doi. org/10.1177/1043454208317237

9. Welch SB. Can the Death of a Child Be Good? J Pediatr Nurs [Internet] 2008 Apr;23(2)120-5. Available from: https://doi.org/10.1016/j. pedn.2007.08.015

10. Conselho Nacional dos Direitos da Criança e do Adolescente (CONANDA) (BR). Resolução № 41 de 19 de outubro de 1995. Direitos da criança e do adolescente hospitalizados. Brasília (DF): Diário Oficial da União; 1995.

11. Souza LF, Misko MD, Silva L, Poles K, Santos MR, Bousso RS Morte digna da criança: percepção de enfermeiros de uma unidade de oncologia. Rev Esc Enferm USP [Internet]. 2013 Feb;47(1)30-7. Available from: http://dx.doi.org/10.1590/S0080-62342013000100004

12. Santos RA, Moreira MCN. Resiliência e morte: o profissional de enfermagem frente ao cuidado de crianças e adolescentes no processo de finitude da vida. Rev Ciênc Saúde Coletiva [Internet]. 2014 Dec;19(12):4869-78. Available from: http://dx.doi.org/10.1590/1413 812320141912.18862013

13. Furingsten $L$, Sjogren $R$, Forsner M. Ethical challenges when caring for dying children. Nurs Ethics [Internet]. 2015 Mar;22(2):176-87. Available from: https://doi.org/10.1177\%2F0969733014533234

14. Patino CM, Ferreira JC. Critérios de inclusão e exclusão em estudos de pesquisa: definições e porque eles importam. J Bras Pneumol [Internet] 2018 Mar/Apr;44(2):84. Available from: http://dx.doi.org/10.1590/S180637562018000000088

15. Hoffmann MV, Oliveira ICS. Entrevista não-diretiva: uma possibilidade de abordagem em grupo. Rev Bras Enferm [Internet]. 2009 Nov/ Dec;62(6)923-7. Available from: http://dx.doi.org/10.1590/S003471672009000600021

16. Minayo MCS. O desafio do conhecimento: pesquisa qualitativa em saúde. 2010. São Paulo: Hucitec/Abrasco; 2014. 
17. Minayo MCS. Amostragem e saturação em pesquisa qualitativa: consensos e controvérsias. Rev Pesq Qualit (São Paulo) [Internet]. 2017 Apr;5(7):1-12. Available from: https://edisciplinas.usp.br/pluginfile. php/4111455/mod_resource/content/1/Minayosaturacao.pdf

18. Neutzling BRS, Barlem JGT, Barlem ELD, Hirsch CD, Pereira LA, Schallenberguer CD. Em defesa dos direitos da criança no ambiente hospitalar: o exercício da advocacia em saúde pelos enfermeiros. Esc Anna Nery [Internet]. 2017;21(1):e20170025. Available from: http:// dx.doi.org/10.5935/1414-8145.20170025

19. Menin GE, Penttenon MK. Terminalidade da vida infantil: percepções e sentimentos de enfermeiros. Rev Bioét [Internet]. $2015 \mathrm{Sep} /$ Dec;23(3):608-14. Available from: http://dx.doi.org/10.1590/198380422015233097
20. Arantes ACQ. A morte é um dia que vale a pena viver. Rio de Janeiro: Casa da Palavra; 2016. 192 p.

21. Färber SS. Tanatologia clínica e cuidados paliativos: facilitadores do luto oncológico pediátrico. Cad Saúde Coletiva [Internet]. $2013 \mathrm{Jul} /$ Sep;21(3):267-71. Available from: http://dx.doi.org/10.1590/S1414462X2013000300006

22. Ribeiro JP, Gomes GC, Thofehrn MB, Porto AR, Rodrigues LPV. Ambiente de pediatria: aspectos que auxiliam no processo de trabalho e na produção de saúde. Rev Enferm UFPE On Line (Recife) [Internet] 2017 Dec;11(Supl. 12):5275-81. Available from: file:///C:/Users/susana/ Downloads/22786-76644-1-PB.pdf

a Article extracted from the Master Dissertation entitled "The Right to the Worthy Death of the Hospitalized Child: Nursing actions", by Nathalia Cristine Schuengue Pimentel Cholbi, under orientation of Isabel Cristina dos Santos Oliveira, presented to the Post-graduation and Research Program of the School of Nursing Anna Nery (EEAN) of the Federal University of Rio de Janeiro - UFRJ. Rio de Janeiro (RJ), Brazil, in December 2018. 